\title{
Review \#105
}

\begin{tabular}{ll}
\hline Review by: & Bernhard Hurch \\
Reviewer's e-mail/address: & Bernhard \\
& O.Univ.Prof. \\
& \\
& Sprachwissenschaft / Linguistics \\
& Institutsvorstand / Head of \\
& Institute \\
& Universität Graz \\
& Merangasse \\
& \\
& \\
&
\end{tabular}

Book reviewed:

Hugo Schuchardt, Textes théoriques et de réflexion (1885-1925).

Edited electronically by: Armin Schwegler on 1/9/13
Editing completed on: Armin Schwegler on 1/17/13

Run through dictionary? 1/15/13

Checked all refs. in text

against bibliography 1/9/13

Copyright forms sent?: 1/9/13

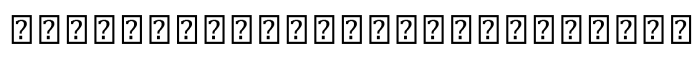

Additional comments:

READY TO GO. No special phonetic characters 
Hugo Schuchardt, Textes théoriques et de réflexion (1885-1925). Édition bilingue établie par Robert Nicolaï et Andrée Tabouret-Keller, avec la collaboration de Pierre Caussat et Elisabetta Carpitelli. Limoges: Éditions Lambert-Lucas. 2011. ISBN 978-2-915806-16-8. $€ 30.00$ or approx. US \$40.00. [To order, visit http://www.lambert-lucas.com/]

\section{Reviewed by Bernhard Hurch, Universität Graz}

The point of a review of a book of this nature is to focus not on what Schuchardt had to say, which has been thoroughly discussed for over a century, but on the editors' selection, translation and handling of his materials. ${ }^{1}$ In an era in which the bibliographies in linguistic publications rarely contain a citation more than five years old, the appearance of a volume containing (re-)edited and translated texts, some of which are more than 125 years old, is definitely a welcome event. One of the less beneficial developments in contemporary linguistics over the past several decades is that the discourse has come to be mostly in English. France is the only country officially opposing this situation: It promotes the translation and publication of historically and scientifically important texts in order to make them available to French readers. Schuchardt himself corresponded and wrote in well over a dozen languages. Besides all Romance and the major Germanic and Slavic languages, his competence extended to less common ones like Basque, Welsh, Hungarian, Georgian among others. His linguistic range may seem very broad by today's standards, but in the scientific world of that era his abilities were not unique.

Seventeen of Schuchardt's scholarly titles were originally written in French. Inexplicably, the editors of this volume, which should serve as an introduction of Schuchardt to the French-speaking public, neither list these items, nor give any reference to them. ${ }^{2}$ Schuchardt had excellent knowledge of the language - his mother was a French native speaker from Geneva.

In 1885 he received the Prix Volney (one of the most coveted academic awards of the French Academy at the time) for his book Slawo-deutsches und Slawo-italienisches, a pioneering study on language mixing. It became the basis of his later studies on creole languages. Written in German, it was well received in the French academic circles of the time. The expectation that scientific discourse can be polyglot has since been lost.

The aim of the present French volume is to offer a bilingual edition of a selection of important articles. A short foreword by the main editor Robert Nicolaï gives some brief editorial remarks. Unfortunately, it is too brief to elucidate why these particular articles were chosen.

The articles are grouped into three sections: (1) The Lautgesetz debate, (2) "Trois points forts parmi d'autres", and (3) "Distanciations". The volume concludes with a final section, in the style of an annotated person index by Andrée Tabouret-Keller.

The thematic choice for the three sections - each apparently the responsibility of one of the sub-editors - and the criteria for the selection of the papers within the sections is not clear. The main editor himself admits to arbitrariness (p. 10) in the "Introduction". For the remainder of this review I will discuss the individual sections in some detail.

I thank Richard Rhodes (Berkeley) for correcting and improving the English version of this text.

The electronic Hugo Schuchardt Archiv at the Institute of Linguistics (University of Graz) not only explicitly lists the foreign language production and the later published translations into other languages, but also provides the interested reader with full text versions of Schuchardt's complete writings and translations (http://schuchardt.uni-graz.at). 
The debate over sound laws and the neo-grammarians is a standard topic in the history of linguistics, and Schuchardt was an important participant in it. The first section contains a short introduction by Tabouret-Keller and three papers: Schuchardt's original 1885 polemic 'On sound laws. Against neo-grammarians', a reaction to this paper by Victor Henry from 1886 and Schuchardt's response to Henry, also from 1886. These latter two papers were originally written and published in French. To some extent, this section offers a good reason to question both the usefulness of a bilingual edition and the quality of this one. Schuchardt's 1885 paper was widely read in the linguistic world of his time because it formulated many of the arguments offered by opponents of the neo-grammarian movement, both general and specific. Schuchardt's paper was part of the canon of pros and cons of the theory, a canon that demonstrates just how much of the linguistic discussion of the late 19th century was multilingual. The reaction by Henry was just one expression of that multilingual discussion. The fact that Schuchardt himself answered Henry in French is another. Scholarly discourse on the topic involved contributions written in the various major languages of Europe without special note. French scholars of the caliber of, for example, Antoine Meillet who contributed significantly to the theory of historical linguistics were familiar with the relevant contributions in other languages. The standard collection of articles on the sound law debate, Wilbur (1977), brings together all the relevant papers from the so-called Kampfjahr of 1885. Tabouret-Keller seems unaware of the existence of Wilbur's edition and especially of Wilbur's very remarkable introductory essay. Similar criticism can be leveled at most of the volume under review: the secondary literature used by the volume editors to critically evaluate Schuchardt is almost exclusively that which has either been written in or translated into French. In so doing, it ignores the genuinely international and multilingual character of the debates themselves.

As if that were not bad enough, the translator and editor of Schuchardt's sound paper makes some truly embarrassing mistakes. She plays fast and loose with Schuchardt's original text - starting with the title. As his own article in French attests, Schuchardt preferred the translation 'Sur les lois phonétiques'. But the editor/translator renders it 'Des lois phonétiques' (p. 25, cp. also the table of contents). This might be seen as a stylistic choice, but it reflects a problematic lack of respect for the original text. She goes on to comment on Schuchardt's use of the term dialektisch, which she mistakenly thinks should be dialektal, and attributes his use of dialektisch to a "coquille" (p. 74), apparently unaware that the use of dialektisch was commonplace at the time and is found from Humboldt on in many important texts of the 19th century. More crucially, the editor/translator goes so far as to correct Schuchardt's German text (and provides a relevant footnote - on pages 44 and 74, respectively) because she misunderstood the original. I could go on, but space does not permit the enumeration of the many gravamina of this type.

The volume under review also suffers from a very serious problem with typos. Although there are fewer in the German originals, they are all too frequent in the editorial remarks, in the bibliographies, and especially in the person cited index. On page 256, for instance, not one single German title is spelt correctly. On the same page, the number of misspelt German words seems to exceed the number of the correct ones. Again space does not permit further comment. Suffice it to say that this is hardly a recommendation for an edition — bilingual or not.

I should also add that the first section of the present volume is a step backwards in Schuchardt studies. It flies in the face of the fact that the discussion of Schuchardt has been international and multilingual since the beginning, and by making the discussion almost entirely Francocentric, it potentially serves to isolate French linguistics in a way that, one 
hundred years ago, it was not. Furthermore, in the 21st-century context where English is the lingua franca, it is also a step backwards in the further development of Schuchardt studies.

Beyond that substantial problem there are questionable assertions about Schuchardt and his ideas. For example, Tabouret-Keller asserts that the notion of linguistics as a (natural) science is "la position des descendants de Humboldt" (p. 21). She sees the alternative in "Estelle [la linguistique - $\mathrm{BH}$ ] un objet ayant sa propre spécificité? - Ce serait la position de Schuchardt." This artificial opposition is hard to understand, unless she is referring to Alexander von Humboldt rather than Wilhelm. (Alexander was not held in high esteem by Schuchardt.) Tabouret-Keller creates confusion, because, if there was anyone in the late 19th century who looked to the work of Wilhelm von Humboldt, it was Schuchardt (along with Baudouin de Courtenay, Gabelentz, and others). There is a substantial body of literature on that topic, and the present volume implicitly is yet another contribution. ${ }^{3}$

The second section of the volume under review is entitled "Three strong points among others". It offers three crucial papers by Schuchardt:

- Sachen und Wörter

Schuchardt's main contribution to the Wörter und Sachen or Sachen und Wörter framework argues in favor of a close relation between the diachronic development of objects and the words denoting these objects. There are a formidable number of specific Wörter und Sachen studies from his pen - etymologies, comparative ethnology (from weaving techniques to fishnets and many others), etc. - and his influence in this area extended well beyond his death (cp. the Swiss tradition, which substantiated this approach most clearly in Jaberg \& Jud 1928-1940). The introduction by the section editor Elisabetta Carpitelli is brief and, as far as the history of science is concerned, not particularly informative. ${ }^{4}$

- Schuchardt's review of Saussure's Cours de linguistique générale

Schuchardt's review of Saussure's Cours de linguistique générale constitutes another classical text stating fundamental positions of the first decades of the 20th century . There are various readings of this text, but Schuchardt's most intriguing point - to my way of thinking - is that he sees clearly some type of continuity in Saussure with earlier ideas. By this I mean to say that, contrary to the accepted standard reading of Schuchardt, here the author highlights the innovative force of the Cours, thereby stressing the continuation of neogrammarian ideas in pre-structuralist thinking. As regards the present edition, Pierre Caussat's excellent French translation of Schuchardt's review in the book is not entirely new to the French public; rather, it is a slightly re-worked version of what originally appeared in Normand et al. (1978).

- Sprachverwandtschaft ('La parenté des langues')

There is one common thread running through Schuchardt's scholarship: the study of language contact, language mixture, and, most notably, creole languages. The only contribution in this volume on this topic, and then only in the broadest sense, is the third essay of this section: Sprachverwandtschaft ('La parenté des langues'), dated 1917. The presentation by R. Nicolaï unfortunately only draws upon the French context (A. Meillet) and the related discussion of linguistic change. It ignores the fact that this is

3 I will give a single example, probably of most importance to creolists: The frequent Schuchardt quotation that "there exist no un-mixed languages in the world" originates in Humboldt with the very same wording. In the same paragraph, Humboldt urges the study of creole languages.

4 It is an interesting fact, that Michel Foucault's book Les mots et les choses, which exactly matches "Wörter und Sachen," has a different title in German, namely Die Ordnung der Dinge. But as the German translator states in a footnote, this difference in the title goes back to an explicit request by Foucault. It is not by chance that among the few translations from German that Foucault produced (aside from Kant) include works by Leo Spitzer. It is safe to assume that he was acquainted with that debate. As I have suggested elsewhere (Hurch 2006:XXXVIII), Foucault may have been influenced by Spitzer in other respects as well. 
one of Schuchardt's most important papers in the Humboldt tradition. Schuchardt draws attention to the distinction between inner and outer form, between historisch verwandt and elementar verwandt, and between grammar, grammaticalization and the lexicon in relation to the debate about language family/affinity. The same publication also addresses the theme of ergon vs. energeia. Quoting Plank's (1981) essay here is a must, as he well goes beyond the context outlined in this paper. The French translation by a group of students under the guidance of Patrick Sériot and Alexander Schwarz is very good, though unfortunately not without some editorial errors and typos.

The third section also includes two very late articles ("Individualismus" [1923] and "Der Individualismus in der Sprachforschung" [1925]). The section entitled "Distanciations" seems somewhat cryptic, but as such fits quite well within the context of the book. R. Nicolai gives an introduction portraying Schuchardt as a wise old man looking back on his life and work. This introduction is well worth reading. But once again the translation creates some problems. The most self-reflexive and epistemologically oriented part of the volume unfortunately sometimes fails to render the philosophical meanings in a faithful manner. Schuchardt's final sentence in the second essay is an open commitment to rationalism: "Denn die Wissenschaft soll vereinfachen, nicht vervielfachen." French "complexifier", therefore, hardly matches the final verb "vervielfachen". Schuchardt is clearly alluding to Occam's: "Entia non sunt multiplicanda praeter necessitatem."

If the volume under review helps to strengthen a non-routine discussion in France, it will be very welcome. As I have agued above, the edition could have been better executed. We nonetheless appreciate and welcome efforts of this type. Creolists will be disappointed that this volume does not contain any of those writings for which Schuchardt is known best in the discipline. There are indications that a second volume is already underway, which will include a translation of the above-mentioned Prix Volney award winning monograph "Slawodeutsches und Slawo-italienisches" (Schuchardt 1884), Schuchardt's first lengthy discussion of language contact. There is further talk of a third volume on Schuchardt's creolist essays. It is the hope of the current reviewer that the pointed criticism here might contribute to an improvement of any future volumes.

\section{References}

Hurch, Bernhard. 2006. Schuchardt und Spitzer. In Bernhard Hurch (ed.), Leo Spitzers Briefe an Hugo Schuchardt (pp. XIII-L). Berlin: Walter de Gruyter.

Jaberg, Karl \& Jud, Jakob. 1928-1940. Sprach- und Sachatlas Italiens und der Südschweiz. Zofingen: Ringier.

Normand, Claudine et al. (eds.). 1978. Avant Saussure: choix de textes, 1875-1924. Brussels: Éditions Complexe.

Plank, Frans. 1981. Geschichtlich verwandt - elementar verwandt - typologisch verwandt. Linguistische Berichte 74. 35-44.

Schuchardt, Hugo. 1884. Dem Herrn Franz von Miklosich zum 20. Nov. 1883. Slawodeutsches und Slawo-italienisches. Graz: Leuschner und Lubensky.

Wilbur, Terence (ed.). 1977. The lautgesetz-controversy: A documentation. Amsterdam: Benjamins.

Electronic source for a complete edition of Schuchardt's writings:

http://schuchardt.uni-graz.at 